University of Nebraska - Lincoln

DigitalCommons@University of Nebraska - Lincoln

Faculty Publications from the Harold W. Manter Laboratory of Parasitology

1997

\title{
Haplosporidium nelsoni (MSX) Epizootic in the Piscataqua River Estuary (Maine/New Hampshire, U.S.A.)
}

\author{
B. J. Barber \\ University of Maine - Main \\ R. Langan \\ University of New Hampshire - Main Campus \\ T. L. Howell \\ Spiny Creek Shellfish Company (Eliot, Maine, USA)
}

Follow this and additional works at: https://digitalcommons.unl.edu/parasitologyfacpubs

Barber, B. J.; Langan, R.; and Howell, T. L., "Haplosporidium nelsoni (MSX) Epizootic in the Piscataqua River Estuary (Maine/New Hampshire, U.S.A.)" (1997). Faculty Publications from the Harold W. Manter Laboratory of Parasitology. 748.

https://digitalcommons.unl.edu/parasitologyfacpubs/748

This Article is brought to you for free and open access by the Parasitology, Harold W. Manter Laboratory of at DigitalCommons@University of Nebraska - Lincoln. It has been accepted for inclusion in Faculty Publications from the Harold W. Manter Laboratory of Parasitology by an authorized administrator of DigitalCommons@University of Nebraska - Lincoln. 


\section{Haplosporidium nelsoni (MSX) Epizootic in the Piscataqua River Estuary (Maine/New Hampshire, U.S.A.)}

B. J. Barber, R. Langan`, and T. L. Howell†, Department of Animal, Veterinary and Aquatic Sciences, University of Maine, Orono, Maine 04469; *Jackson Estuarine Laboratory, University of New Hampshire, Durham, New Hampshire 03824; and †Spinney Creek Shellfish Co., P.O. Box 310, Eliot, Maine 03903

ABSTRACT: A major epizootic of Haplosporidium nelsoni occurred during 1995 in the Piscataqua River Estuary, near the northern distributional limit of the parasite. Prevalence of $H$. nelsoni in samples of oysters, Crassostrea virginica, collected between 5 September and 18 December 1995 from sites in Maine and New Hampshire ranged from 15 to $81 \%$, with up to $50 \%$ systemic infections. Associated proportions of dead oysters ranged from 25 to $83 \%$. The epizootic was most likely triggered by unusually warm and dry climatic conditions in 1995 that resulted in a temperature and salinity regime in the estuary that favored the parasite.

The protozoan Haplosporidium nelsoni, causative agent of MSX disease, began killing oysters, Crassostrea virginica, in Delaware Bay in 1957 and within $3 \mathrm{yr}$ caused 60\% mortality of oysters in seed areas and 90-95\% mortality of oysters planted on leased grounds (Haskin et al., 1966; Haskin and Ford, 1979; Ford and Haskin, 1982; Haskin and Andrews, 1988). Two years later, $H$. nelsoni appeared in Chesapeake Bay and within 2-3 yr caused $90-95 \%$ mortality of oysters in Virginia (Andrews and Wood, 1967; Andrews, 1968). Haplosporidium nelsoni has, in large part, been responsible for the decline in oyster harvests throughout the mid-Atlantic region since 1959 (Ford and Haskin, 1982; Burreson and Andrews, 1988; Ford, 1988; Haskin and Andrews, 1988).

Haplosporidium nelsoni is presently distributed from Maine to Florida (Haskin and Andrews, 1988; Sindermann, 1990). Since 1959, range expansion of $H$. nelsoni within and beyond Chesapeake and Delaware bays occurred during periods of drought in 1963-1966, 1980-1982, and 1985-1987 (Andrews, 1968; Burreson and Andrews, 1988). Epizootics associated with H. nelsoni, which were initially confined to Delaware and Chesapeake bays, have since occurred at Bayville, New York $(90 \%$ mortality from 1983 to 1985) and Cotuit Bay, Massachusetts (85\% mortality from 1984 to 1985) (Haskin and Andrews, 1988; Matthiessen et al., 1990). Although H. nelsoni has been found as far north as Maine, epizootics north of Cape Cod, Massachusetts, have not previously been reported.

Occurrence of $H$. nelsoni is regulated primarily by salinity and to a lesser extent by temperature. Haplosporidium nelsoni cannot survive below 10 ppt (Ford, 1985a; Ford and Haskin, 1988). Infection prevalence and intensity are directly correlated with salinity between 10 and $20 \mathrm{ppt} ; 15 \mathrm{ppt}$ is required for oysters to demonstrate infections, and serious mortalities occur at 18-20 ppt (Haskin and Ford, 1982; Burreson and Andrews, 1988). Parasite proliferation is greatest above $20 \mathrm{ppt}$ (Andrews, 1968). Infection of new hosts by $H$. nelsoni occurs primarily in early summer, when water temperature is increasing, and resultant mortality peaks in late summer and early fall; parasite prevalence and related mortality decrease in late fall with decreasing temperature (Andrews, 1966; Ford, 1985b). Thus, the abundance of $H$. nelsoni increases during periods of summer drought and diminishes in response to spring freshets (Burreson and Andrews, 1988; Calvo and Burreson, 1996).

The Piscataqua River Estuary forms a portion of the boundary between New Hampshire and Maine (Fig. 1). Natural beds of $C$ : virginica in this estuary are harvested commercially in Maine (Piscataqua River) and harvested recreationally in New Hampshire (Little Bay and Great Bay). Haplosporidium nelsoni was first seen in Maine oysters (including samples from the Piscataqua River) in 1983 (Sherburne and Bean, 1991). More recently, prevalence of $H$. nelsoni in oysters from the Piscataqua River was 0\% (0/25) in August 1993 and 15\% (3/20) in October 1994 (B. Barber, unpubl. obs.). Haplosporidium nelsoni was thus present in the Piscataqua River at a low level for at least $12 \mathrm{yr}$ without development of an epizootic.

Unusual mortalities of oysters were observed, however, by harvesters in the Piscataqua River beginning in late August 1995. In a sample obtained from Summer Bed on 5 September 1995, prevalence of a parasite resembling $H$. nelsoni was $72 \%$ $(18 / 25)$, with $10 / 25$ oysters $(40 \%)$ having systemic infections (Table I). Additional samples were obtained from 4 locations in the Piscataqua River, Maine on 27 October 1995 and from 3 locations in Great Bay and Little Bay, New Hampshire on 6 November and 18 December 1995 (Fig. 1; Table I). The numbers of live and dead (empty valves still connected) oysters in approximately $15 \mathrm{~L}$ of dredged material were counted on 27 October at the Piscataqua River sites. Live oysters $(n=16-20)$ were measured (shell height, $\mathrm{mm}$ ), shucked, and placed in Dietrich's fixative. Standard cross sections of oysters were dehydrated, cleared, and embedded in Paraplast (Howard and Smith, 1983). Sections ( $5 \mu \mathrm{m}$ thickness) were stained with Shandon instant hematoxylin and eosin $\mathrm{Y}$ and coverslipped. Additional sections were processed for in situ hybridization with a DNA probe specific for $H$. nelsoni (Stokes and Burreson, 1995). Slides were examined at $100 \times$ for the presence of $H$. nelsoni spores and plasmodia. Prevalence (\% oysters infected) and the percentage of oysters having systemic infections (involving all tissues) were recorded.

Mean shell height of oysters ranged from 74 to $102 \mathrm{~mm}$ (Table I). Initial identification of the parasite as $H$. nelsoni using routine histology was verified with the DNA probe. In the Piscataqua River, prevalence of $H$. nelsoni infections (15-81\%) and the proportion of systemic infections (5-50\%) and dead oysters $(25-83 \%)$ generally increased with distance upstream (Fig. 1; Table I). Moribund oysters (gapers) found at Salmon Falls were infected with $H$. nelsoni. Recently dead oysters (having no fouling on interior shell surfaces) were found at all locations on the Piscataqua River. In Great Bay and Little Bay, prevalence (15-50\%) and proportion of systemic infections (5$30 \%$ ) both decreased with distance from the Piscataqua River 


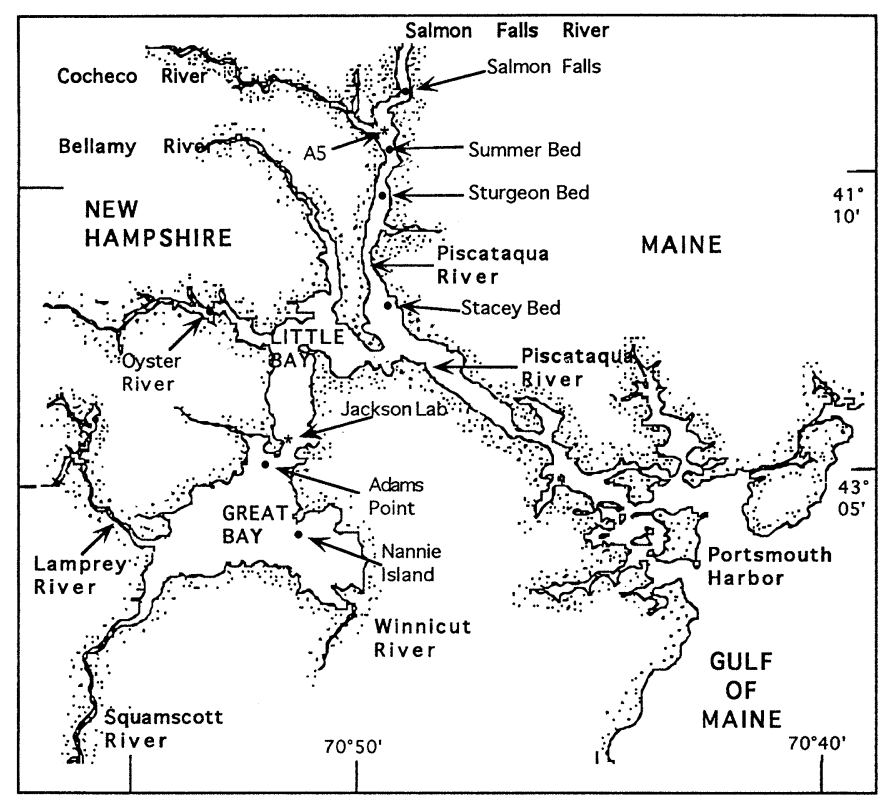

FIGURE 1. Map of Piscataqua River Estuary, showing locations of oyster beds and hydrographic stations.

(Fig. 1; Table I). Spores of H. nelsoni were not observed in any oyster.

To determine a possible cause of the observed epizootic, long-term hydrological and climatological data were examined. In the Piscataqua River, surface temperature (thermometer) and salinity (refractometer) data were collected monthly at station A5, between the Salmon Falls Bed and the Summer Bed beginning in 1989. Although temperature data were not available for 1995, maximum summer temperatures were 20-26 C in all years and increased between 1992 and 1994 (Fig. 2). More importantly, maximum (summer) salinity at station A5 has exceeded 25 ppt since 1993, a considerable increase over the previous $4 \mathrm{yr}$ (Fig. 2). Monthly means of water temperature and salinity in Great Bay, calculated from data collected with dataloggers adjacent to the Jackson Estuarine Laboratory since 1989 , are also revealing. While maximum monthly temperature

TABLE I. Mean shell height (mm) of oysters, prevalence (\%), and systemic infections (\%) of Haplosporidium nelsoni, and proportion of dead oysters (\%) in samples collected from the Piscataqua River Estuary in 1995; nd indicates data not available.

\begin{tabular}{|c|c|c|c|c|c|c|}
\hline Location & Date & $\mathrm{n}$ & $\begin{array}{l}\text { Mean } \\
\text { shell } \\
\text { height } \\
(\mathrm{mm})\end{array}$ & $\begin{array}{c}\text { Preva- } \\
\text { lence } \\
(\%)\end{array}$ & $\begin{array}{c}\text { Sys- } \\
\text { temic } \\
\text { infec- } \\
\text { tions } \\
(\%)\end{array}$ & $\begin{array}{c}\text { Dead } \\
(\%)\end{array}$ \\
\hline Salmon Falls & 27 Oct. & 16 & 81.0 & 81 & 50 & 83 \\
\hline \multirow[t]{2}{*}{ Summer Bed } & 5 Sept. & 25 & 75.6 & 72 & 40 & nd \\
\hline & 27 Oct. & 20 & 74.0 & 70 & 25 & 64 \\
\hline Sturgeon Bed & 27 Oct. & 20 & 75.0 & 65 & 40 & 42 \\
\hline Stacy Bed & 27 Oct. & 20 & 77.0 & 45 & 10 & 25 \\
\hline Oyster River & 18 Dec. & 20 & 102.5 & 50 & 30 & nd \\
\hline Adams Point & 6 Nov. & 20 & 95.0 & 40 & 15 & nd \\
\hline Nannie Island & 6 Nov. & 20 & 95.9 & 15 & 5 & nd \\
\hline
\end{tabular}

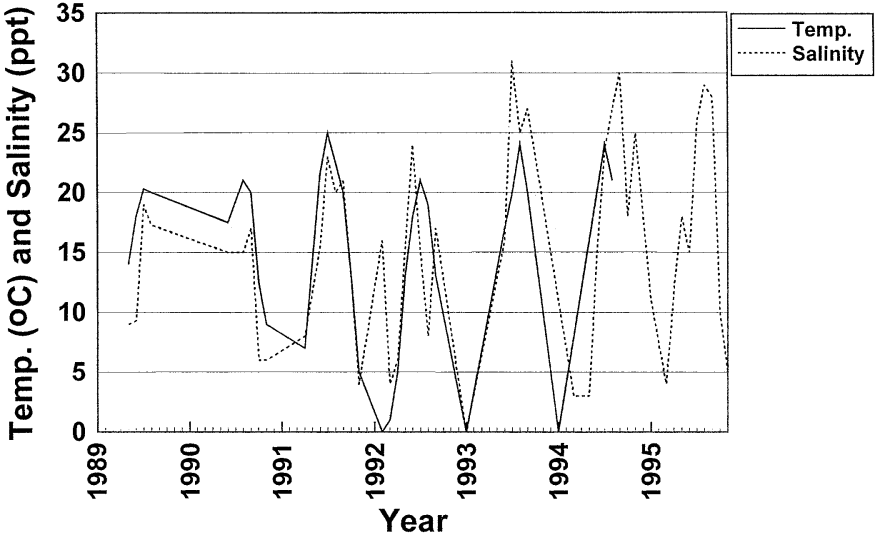

FIGURE 2. Monthly means of temperature (C) and salinity (ppt) at station A5 in the Piscataqua River, Maine, 1989-1995.

has increased yearly since 1992, maximum monthly salinity has increased yearly since 1990 and exceeded 30 ppt in 1995 for the first time on record (Fig. 3). Thus, throughout the Piscataqua River Estuary, summer maxima of both temperature and salinity have recently increased to levels more favorable for proliferation of $H$. nelsoni.

Climatological data obtained from the New Hampshire state meteorologist were used to calculate a cumulative score that was based on the sum of the rank of each year (1895-1995) for each category of (1) air temperature from January to March, (2) air temperature from July to September, (3) runoff from March to April, and (4) runoff from July to September. The lower the runoff and the higher the temperature, the lower the score. Interestingly, 1995 had the second lowest cumulative score since 1896, indicating that 1995 was the warmest, driest year since 1949. The observed increases in mean water temperature and salinity observed in the Piscataqua River Estuary in recent years are thus linked to prevailing climatological conditions.

The cause of the H. nelsoni epizootic in the Piscataqua River Estuary documented here can best be explained by recent trends in climatological factors that influence the estuarine environment. Prior to $1995, H$. nelsoni was present in the Piscataqua

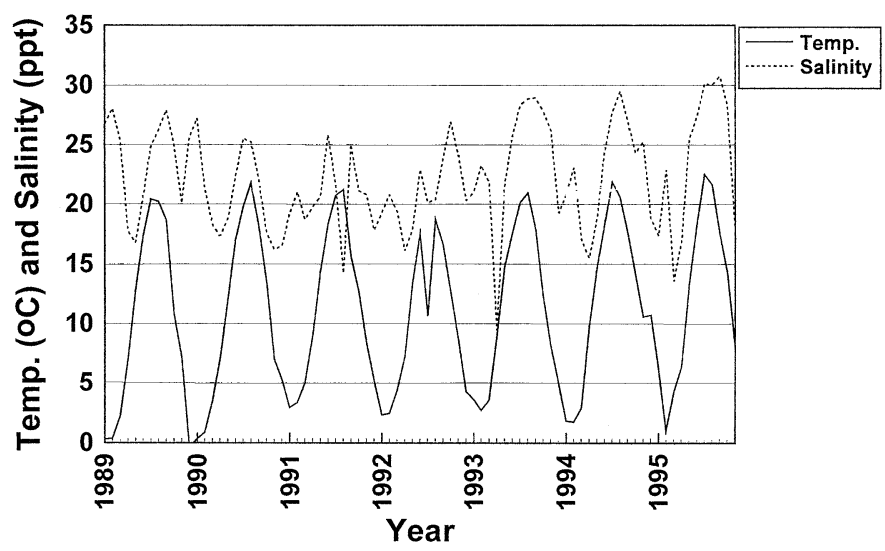

FIGURE 3. Monthly means of temperature (C) and salinity (ppt) adjacent to the Jackson Estuarine Laboratory in Great Bay, New Hampshire, 1989-1995. 
River but was limited by a combination of relatively low temperature and salinity. Since about 1993, mean water temperature and salinity (summer) maxima in the estuary have been gradually increasing to levels favorable for proliferation of $\mathrm{H}$. nelsoni. In 1995, both temperature (15-25 C) and salinity (15-30 ppt) were within the preferred ranges of the parasite for an extended period, allowing for rapid spread and development of the disease throughout the estuary (Haskin and Ford, 1982). Besides affecting parasite physiology directly, increased temperature and salinity could have also influenced abundance and distribution of as yet unidentified intermediate host organisms (Haskin and Andrews, 1988). Thus, given appropriate environmental conditions, $H$. nelsoni can cause serious oyster mortality, even at its northern distributional limit.

The drastic increase in prevalence and intensity (\% systemic infections) of $H$. nelsoni and mortality of oysters seen in the Piscataqua River Estuary in 1995 is similar to that reported from other locations experiencing drought conditions (Andrews, 1968; Burreson and Andrews, 1988). In the James River, Virginia, water temperature in 1995 was generally above the longterm average and streamflow into the bay was below average from February to May. As a result, prevalence of $H$. nelsoni in May (80\%) was the highest ever recorded (Calvo and Burreson, 1996).

Parasite prevalence, intensity, and associated mortality decreased with distance downstream in the Piscataqua River because the lower beds (particularly Stacy Bed) experience greater exposure to seawater from the Gulf of Maine and thus have a temperature range below that preferred by $H$. nelsoni (Haskin and Ford, 1982). Conversely, the uppermost bed (Salmon Falls), being farthest from the ocean, is warmest during periods of summer drought. Also, during periods of low runoff, infective stages of $H$. nelsoni might be less concentrated at locations closer to the mouth of the river due to dilution with ocean water. In Great Bay, the observation of decreasing $H$. nelsoni prevalence with distance from the Piscataqua River might indicate that the focus of infection by $H$. nelsoni is in the Piscataqua River, which contributes a greater proportion of source water to the bay during periods of drought. The fact that spore stages of $H$. nelsoni were not observed in this study is consistent with the general lack of sporulation in adult oysters (Ford and Haskin, 1982; Ford and Tripp, 1996).

We thank the following people: B. Keim for climatological data, L. Livingston for hydrographic data, B. Smith for collecting oysters, D. Beane for histological preparations, N. Stokes for performing the in situ hybridization, and S. Ford and E. Burreson for providing initial manuscript reviews. This is Maine Agricultural and Forestry Experiment Station external publication \#2028.

\section{LITERATURE CITED}

ANDrews, J. D. 1966. Oyster mortality studies in Virginia. V. Epizootiology of MSX, a protistan pathogen of oysters. Ecology 47: 1931.
1968. Oyster mortality studies in Virginia. VII. Review of epizootiology and origin of Minchinia nelsoni. Proceedings of the National Shellfisheries Association 58: 23-36.

, AND J. L. WoOD. 1967. Oyster mortality studies in Virginia. VI. History and distribution of Minchinia nelsoni, a pathogen of oysters, in Virginia. Chesapeake Science 8: 1-13.

BurRESON, E. M., AND J. D. ANDREWs. 1988. Unusual intensification of Chesapeake Bay oyster diseases during recent drought conditions. Proceedings of the Oceans ' 88 Conference, p. 799-802.

Calvo, L. R., AND E. M. BurReson. 1996. Status of the major oyster diseases in Virginia-1995. Marine Resource Report 96-1. Virginia Institute of Marine Science, Gloucester Point, Virginia, $24 \mathrm{p}$.

ForD, S. E. 1985a. Effects of salinity on survival of the MSX parasite Haplosporidium nelsoni (Haskin, Stauber, and Mackin) in oysters. Journal of Shellfish Research 5: 85-90.

1985b. Chronic infections of Haplosporidium nelsoni (MSX) in the oyster Crassostrea virginica. Journal of Invertebrate Pathology 45: $94-107$.

. 1988. Host-parasite interactions in eastern oysters selected for resistance to Haplosporidium nelsoni (MSX) disease: Survival mechanisms against a natural pathogen. American Fisheries Society Special Publication 18: 206-224.

, AND H. H. HASKIN. 1982. History and epizootiology of Haplosporidium nelsoni (MSX), an oyster pathogen in Delaware Bay, 1957-1980. Journal of Invertebrate Pathology 40: 118-141.

, AND - 1988. Comparison of in vitro salinity tolerance of the oyster parasite, Haplosporidium nelsoni (MSX) and hemocytes from the host, Crassostrea virginica. Comparative Biochemistry and Physiology 90A: 183-187.

, AND M. R. TRIPP. 1996. Diseases and defense mechanisms. In The eastern oyster Crassostrea virginica, V. S. Kennedy, R. I. E. Newell, and A. F. Eble (eds.). Maryland Sea Grant College, College Park, Maryland, p. 581-660.

HASKIN, H. H., AND J. D. ANDREws. 1988. Uncertainties and speculations about the life cycle of the eastern oyster pathogen Haplosporidium nelsoni (MSX). American Fisheries Society Special Publication 18: 5-22.

, AND S. E. FORD. 1979. Development of resistance to Minchinia nelsoni (MSX) mortality in laboratory-reared and native oyster stocks in Delaware Bay. Marine Fisheries Review 41: 54-63. stocks in Delaware Bay. Haplosporidium nelsoni (MSX) on Delaware Bay seed oyster beds: A host-parasite relationship along a salinity gradient. Journal of Invertebrate Pathology 40: 388-405.

- L. A. Stauber, AND J. A. MACKIN. 1966. Minchinia nelsoni n. sp. (Haplosporida, Haplosporidiidae): Causative agent of the Delaware Bay oyster epizootic. Science 153: 1414-1415.

Howard, D. W., AND C. S. SMITH. 1983. Histological techniques for marine bivalve molluscs. NOAA Technical Memorandum NMFSF/NEC-25, $97 \mathrm{p}$.

Matthiessen, G. C., S. Y. Feng, and L. Leibovitz. 1990. Patterns of MSX (Haplosporidium nelsoni) infection and subsequent mortality in resistant and susceptible strains of the eastern oyster, Crassostrea virginica (Gmelin, 1791), in New England. Journal of Shellfish Research 9: 359-365.

Sherburne, S. W., AND L. L. BEan. 1991. Final progress report on the pathological testing program to determine the nature and extent of the MSX (Haplosporidium nelsoni) disease problem in Damariscotta River American oysters, Crassostrea virginica. Maine Department of Marine Resources, West Boothbay Harbor, Maine, $10 \mathrm{p}$.

Sindermann, C. J. 1990. Principal diseases of marine fish and shellfish, Vol. 2. Academic Press, Inc., San Diego, California, 516 p.

Stokes, N. A., AND E. M. BURreson. 1995. A sensitive and specific DNA probe for the oyster pathogen Haplosporidium nelsoni. Journal of Eukaryotic Microbiology 42: 350-357. 